\title{
KONSEP PEMBAGIAN HARTA BERSAMA AKIBAT PERCERAIAN DALAM PERKAWINAN SIRI
}

\author{
Nourma Dewi, Raharno; Universitas Islam Batik Surakarta, Jl. KH Agus Salim No. 10 Surakarta; \\ E-mail: Nourmadewi03@gmail.com
}

\begin{abstract}
Abstrak
Pencatatan perkawinan masih sebatas diakui keberadaannya oleh negara bukan syarat utama sahnya perkawinan. Pada prakteknya banyak terjadi perkawinan siri di masyarakat dan perkawinan tersebut terkadang tidak mencapai tujuan perkawinan yang bahagia dan kekal yang menyebabkan terjadinya perceraian. Permasalahan yang perlu dicermati adalah dengan adanya perceraian dari perkawinan siri bagaimana konsep pembagian harta bersama. Penelitian ini menggunakan metode penelitian normatif. Kompilasi Hukum Islam mengatur apabila perkawinan tidak dapat dibuktikan dengan akta perkawinan maka dapat dilakukan penetapan pengadilan atau isbat nikah. Setelah adanya penetapan perkawinan, pembagian harta bersama dapat dilakukan sesuai dengan Pasal 37 Undang-Undang Perkawinan dan Pasal 97 Kompilasi Hukum Islam.
\end{abstract}

Kata kunci: Perkawinan Sirri, Harta Bersama, Perceraian

\section{Abstract}

Marriage registration is still limited to the existence recognized by the state is not the main condition of the legality of the marriage. In practice, many sirri marriages occur in the community and such marriages sometimes do not achieve the goal of a happy and everlasting marriage that causes divorce. The problem that needs to be examined is the divorce from the sirri marriage how the concept of division of shared assets. This research uses normative research methods. KHI regulates the determination of marriage by the court or itsbat marriage. After the stipulation results in the enactment of the law of joint sharing as regulated in Article 37 of the UUP and Article 97 of KHI.

Keywords: Sirri Marriage, Joint Property, Divorce

\section{PENDAHULUAN}

Perkawinan merupakan ikatan lahir dan batin yang kuat antara pria dan wanita sebagai suami isteri untuk membentuk keluarga. Di dalam Kompilasi Hukum Islam melaksanakan perkawinan berarti mentaati perintah Allah dan merupakan ibadah.

Pasal 2 Undang-Undang Perkawinan menyatakan bahwa perkawinan dikatakan sah apabila:

a. Telah dilangsungkan menurut hukum agama dan kepercayaan masing-masing;

b. Dicatat menurut peraturan perundang-undangan.

Di dalam Penjelasan Pasal 2 Undang-Undang Perkawinan hanya menjelaskan tentang Pasal 2 ayat (1) saja, yaitu sebagai berikut :

Adanya Pasal 2 ayat (1) menegaskan perkawinan di Indonesia harus atau wajib dilaksanakan sesuai hukum agama dan kepercayaan yang dianut masing-masing warga negara Indonesia serta tidak bertentangan dengan peraturan perundang-undangan. Hal tersebut sesuai dengan sila pertama pancasila. Sedangkan Pasal 2 ayat (2) menyatakan bahwa perkawinan dicatat menurut peraturan perundang-undangan menimbulkan pro 
kontra apakah hal termasuk syarah sahnya perkawinan atau sebagai persyaratan administratif sehingga tidak mempengaruhi sahnya perkawinan.

Pada prakteknya, banyak masyarakat yang melakukan perkawinan sirri dimana perkawinan tersebut sah menurut agamanya akan tetapi tidak melakukan pencatatan perkawinan kepada pejabat yang berwenang dengan berbagai alasan ${ }^{1}$ seperti meningkatkan ekonomi keluarga, kendala keinginan berpoligami, budaya masyarakat, perbaikan ekonomi, dan lain sebagainya.

Kehidupan pernikahan yang diharapkan membentuk keluarga yang kekal dan bahagia yang berlangsung bukan hanya sehari, seminggu, atau sebulan tetapi sampai maut memisahkan. Akan tetapi, dalam kehidupan berumah tangga dimana pada mulanya didasari dengan cinta dan kasih sayang pada perjalanannya terjadi berbagai macam permasalahan atau cobaan terutama di kompleksitas dimana berpengaruh pada keutuhan rumah tangga yang sudah dibina sehingga menyebabkan putusnya ikatan perkawinan. Putusnya perkawinan salah satunya disebabkan karena terjadinya perceraian.

Perceraian tentunya menimbulkan akibat hukum bagi hak suami dan istri yang berpisah. Jika perkawinan yang sah dicatatkan tentunya akan mempunyai akibat hukum yang dilindungi oleh peraturan perundang-undangan, akan tetapi jika tidak dicatatkan belum ada peraturan yang khusus mengaturnya. Salah satunya adalah mengenai harta bersama.

Harta bersama atau harta gono gini adalah percampuran harta suami isteri terhitung sejak akad nikah terlaksana. Harta bersama disini tidak termasuk harta bawaan, waris, hibah dan hadiah yang diperoleh masing-masing suami isteri. Di Indonesia, penghaturan terkait harta bersama berada di Pasal 119 KUHPerdata, Bab VII tentang harta benda perkawinan Undang-Undang Nomor 1 Tahun 1974 tentang perkawinan yang terdiri dari Pasal 35, Pasal 36, dan Pasal 37, Pasal 1 huruf e dan f, Pasal 89, Pasal 90, Pasal 94, dan Pasal 96 ayat (1) Kompilasi Hukum Islam.

Peraturan-peraturan tersebut dilakukan oleh pembagian harta bersama yang diselesaikan melalui peradilan. Akan tetapi, jika perkawinan yang dilakukan adalah perkawinan sirri apakah konsep pembagian harta bersama tersebut berlaku dan para pihak bisa mendapatkan haknya walaupun perkawinan tersebut sah secara agama dan tidak dicatatkan.

\section{Rumusan Masalah}

Berangkat dari latar belakang di atas maka dapat diambil rumusan masalah: Bagaimana konsep pembagian harta bersama akibat perceraian dalam perkawinan siri?

\section{METODE PENELITIAN}

Jenis penelitian dalam penelitian hukum ini menggunakan metode penelitian hukum normatif. Menggunakan pendekatan peraturan perundang-undangan yaitu Undang- 
Undang Nomor 1 Tahun 1974 tentang Perkawinan dan Kompilasi Hukum Islam serta pendekatan kasus.

\section{PEMBAHASAN}

\section{Sahnya Perkawinan}

Perkawinan merupakan akad, ikatan lahir dan batin yang kuat antara seorang pria dan wanita sebagai suami isteri sebagai bentuk ketaatan terhadap Allah dan melaksanakannya merupakan ibadah. Perkawinan dilaksanakan bertujuan untuk membentuk keluarga yang bahagia dan kekal sehingga dalam pelaksanaannya tentunya harus sesuai dengan syarat dan rukun perkawinan.

Syarat-syarat melaksanakan perkawinan terdapat dalam Pasal 6 dan Pasal 7 UndangUndang Perkawinan. Antara lain :

a. Kedua belah pihak sepakat untuk melangsungkan perkawinan tanpa adanya unsur paksaan, kekhilafan maupun penipuan;

b. Mendapatkan izin dari kedua orang tua jika belum mencapai umur 21 tahun;

c. Batas usia minimal pria (calon suami) sembilan belas tahun dan wanita (calon isteri) 16 tahun;

d. Calon suami dan calon isteri belum terikat tali perkawinan;

e. Wanita atau calon isteri yang akan melaksanakan perkawinan untuk keduakalinya harus sudah melewati masa tunggu atau masa iddah.

Sesuai Pasal 2 ayat (1) Undang-Undang Perkawinan, perkawinan sah jika dilaksanakan menurut agama dan kepercayaan masing-masing. Pasal 2 ayat (2) menyatakan perkawinan dicatat menurut peraturan perundang-undangan. Peraturan ini menjadi perdebatan ahli hukum dan dipahami berbeda-beda oleh masyarakat apakah sahnya perkawinan cukup dengan dilaksanakan sesuai dengan agama dan kepercayaan ataukah pencatatan perkawinan tersebut menjadi syarat wajib untuk menyatakan sahnya perkawinan.

\section{Perkawinan Siri}

Pemaknaan perkawinan siri di dalam masyarakat dipahami dengan berbagai perspektif, yaitu :

a. Perkawinan yang dirahasiakan dimana tidak memenuhi syarat-syarat dan rukun perkawinan yang sah. Contoh ${ }^{2}$ : pernikahan dilaksanakan tanpa wali, dilaksanakan untuk memuaskan nafsu atau syahwat belaka seperti praktik kawin kontrak yang pada praktiknya banyak dilakukan oleh masyarakat.

b. Perkawinan yang dilaksanakan sesuai dengan agama dan kepercayaan masingmasing, memenuhi syarat-syarat dan rukun perkawinan tetapi tidak dicatatkan sesuai dengan peraturan perundang-undangan. Di dalam masyarakat perkawinan ini disebut dengan perkawinan di bawah tangan. Hal tersebut dilakukan oleh masyarakat dengan

2 Kementerian Pemberdayaan Perempuan dan Perlindungan Anak, Perkawinan Sirri dan Dampaknya di Provinsi Jawa Barat, https://www.kemenpppa.go.id/lib/uploads/list/34529laporan-riset-perkawinan-sirri-dan-dampaknya.pdf, diakses pada 25 Juli 2019 Pukul 08.20. 
berbagai alasan, contoh ${ }^{3}$ : tidak mampu membayar administrasi pencatatan perkawinan, ingin berpoligami, untuk pegawai negeri ingin menikah lebih dari satu kali sementara peraturannya melarang hal tersebut.

Perkawinan sirri yang dimaksud dalam penelitian ini adalah perkawinan di bawah tangan yang dilaksanakan sesuai dengan agama dan kepercayaan masing-masing, dilaksanakan sesuai dengan syarat dan rukun Islam.

\section{Harta Bersama}

a. Harta Bersama Menurut Kompilasi Hukum Islam

Hukum islam mengatur mengenai mas kawin serta hak milik pria dan wanita akan tetapi tidak mengatur mengenai harta bawaan dan harta bersama dalam akibat adanya tali perkawinan. ${ }^{4} \mathrm{Di}$ dalam hukum islam, harta kekayaaan di dalam perkawinan atau syirkah adalah harta yang diperoleh bersama maupun sendirisendiri oleh suami isteri selama dalam ikatan perkawinan dan disebut harta bersama tanpa mempersoalkan siapa yang memberikan sumbangsih terbanyak terhadap harta tersebut dan terdaftar atas nama siapa. Di dalam Pasal 97 Kompilasi Hukum Islam menjelaskan janda atau duda cerai hidup, masing-masing mendapatkan seperdua $(1 / 2)$ dari harta bersama selama tidak diperjanjikan lain di dalam perjanjian perkawinan.

b. Harta bersama menurut Undang-Undang Nomor 1 Tahun 1974 tentang Perkawinan

Salah satu akibat hukum perkawinan yang sah adalah harta benda perkawinan. Harta benda perkawinan di atur dalam Bab VII tentang harta benda perkawinan Undang-Undang Nomor 1 Tahun 1974 tentang Perkawinan Pasal 35, Pasal 36, dan Pasal 37. Ketentuan dalam Pasal 35 ayat (1) dan ayat (2) mengatur mengenai penguasaan harta kekayaan yang diperoleh selama perkawinan atau harta bersama berada di bawah suami isteri. Sedangkan harta bawaan atau harta masing-masing dari suami isteri serta harta yang diperoleh karena warisan dikuasai masing-masing. Pasal 36 mengatur bahwa perbuatan hukum terhadap harta bersama harus dengan persetujuan kedua belah pihak suami isteri sedangkan mengenai harta bawaan, suami maupun isteri mempunyai hak sepenuhnya pada harta masing-masing mereka.

Dari peraturan di atas, dapat disimpulkan bahwa harta bersama dimulai sejak terjadinya akad atau ikatan perkawinan antara suami isteri sampai putusnya perkawinan. Harta bersama disini tidak melihat siapa yang memberikan pendapatan yang lebih banyak maupun pembedaan dari hasil kerja suami atau isteri. Penggunaan harta bersama harus melalui persetujuan kedua belah pihak baik yaitu suami dan isteri. Jika salah satu pihak isteri atau suami tidak menyetujuinya, maka perbuatan hukum atau penggunaan harta bersama tidak dapat terlaksana. Hal tersebut menunjukkan keseimbangan kedudukan kedua belah pihak, suami isteri atas harta bersama.

\footnotetext{
${ }^{3}$ Ibid.

${ }^{4}$ Hilman Hadikusuma, Hukum Perkawinan Indonesia Menurut Perundangan, Hukum Adat, Hukum Agama, Bandung: Mandar Maju, 2003, h. 117.
} 
Tujuan pembedaan harta bawaan dan harta bersama erat kaitannya dengan perkawinan dan pewarisan. Di dalam perkawinan pembedaan tersebut bertujuan untuk menetapkan bagian masing-masing suami isteri atas harta, sementara dalam pewarisan bertujuan untuk menetapkan harta peninggalan.

Terkait dengan jumlah pembagian harta bersama, Pasal 37 Undang-Undang Perkawinan menyatakan apabila putusnya perkawinan dikarenakan perceraian maka harta benda diatur menurut hukumnya masing-masing. Pasal tersebut tidak mengatur dengan tegas yang dimaksud dengan hukumnya masing-masing tersebut apakah hukum agama, hukum adat atau hukum lainnya, sedangkan pada praktiknya perkawinan terkadang dilakukan oleh pasangan yang berbeda agama atau kepercayaannya.

\section{Konsep Pembagian Harta Bersama Akibat Perceraian dalam Perkawinan Siri}

Pembentukan hukum nasional tentunya memperhatikan kaidah sopan santun, kaidah kesusilaan, kaidah kepercayaan, kaidah keagamaan. kaidah keagamaan ditujukan untuk kehidupan beriman dan merupakan bentuk kewajiban manusia untuk Tuhan dan kepada dirinya. ${ }^{5}$ Salah satu aspek pembentukan hukum nasional adalah melihat kaidah kegamaan/kepercayaan sesuai dengan sila pertama pancasila "Ketuhanan Yang Maha Esa".

Pasal 2 ayat (1) UUP menyatakan bahwa perkawinan adalah sah jika dilakukan menurut agama dan kepercayaan masing-masing dilanjutkan pada ayat (2) perkawinan dicatat menurut peraturan perundang-undangan yang berlaku.

Terkait pencatatan perkawinan walaupun telah diatur dalam undang-undang masih menjadi perdebatan apakah pencatatan perkawinan sifatnya wajib sebagai syarat sahnya perkawinan atau tidak. Berikut adalah pandangan masyarakat terkait ketentuan pencatatan perkawinan : 6

a. Pendapat bahwa pencatatan perkawinan merupakan bagian syarat sahnya perkawinan. Para ahli hukum ini berpendapat bahwa sahnya perkawinan dimulai setelah adanya pencatatan perkawinan.

b. Kelompok yang tidak sependapat bahwa pencatatan perkawinan merupakan salah satu syarat sahnya perkawinan. Pencatatan perkawinan hanyalah sekedar urusan administrasi belaka. Perkawinan adalah sah jika dilakukan menurut tata cara agama atau kepercayaan yang berlaku di Indonesia.

Berdasarkan forum ijtima' para ulama maka perkawinan di bawah tangan atau perkawinan sirri hukumnya sah selama memenuhi rukun dan syarat nikah. Akan tetapi jika di kemudian hari membawa kemudharatan maka perkawinan tersebut menjadi

\footnotetext{
5 Sudikno Mertokusumo, Mengenal Hukum Suatu Pengantar, Yogyakarta: Penerbit Liberty Yogyakarta, 2003, h.5.

6 Itsnaatul Latifah, Pencatatan Perkawinan : Melacak Akar Budaya Hukum dan Respon Masyarakat Indonesia terhadap Pencatatan Perkawinan, Jurnal Al Mazahib, Vol. 3 , No. 1, Juni 2015, h. 50.
} 
haram.7 Contohnya menelantarkan isteri dan anak-anaknya.

Pasal 100 Kitab Undang-Undang Hukum Perdata menentukan bahwa sebuah perkawinan dibuktikan dengan akta perkawinan yang dibuat oleh pegawai catatan sipil yang melangsungkan perkawinan tersebut. Tata cara pencatatan perkawinan diatur dalam Bab II Pasal 2 sampai Pasal 9 Peraturan Pemerintah Nomor 9 Tahun 1975 Tentang Pelaksanaan Undang-Undang Nomor 1 Tahun 1974 Tentang Perkawinan.Apabila perkawinan tidak dapat dibuktikan dengan akta perkawinan seperti perkawinan di bawah tangan atau perkawinan sirri maka menurut Pasal 36 Undang-Undang Nomor 23 Tahun 2006 Tentang Administrasi Kependudukan, pencatatan perkawinan dilakukan setelah adanya penetapan pengadilan.

Kompilasi Hukum Islam Pasal 7 ayat 2, ayat 3, dan ayat 4 menentukan bahwa dalam hal perkawinan tidak dapat dibuktikan dengan akta perkawinan, maka dapat mengajukan isbat nikah ke Pengadilan Agama. Isbat nikah dapat diajukan oleh isteri, suami, sanak-anak mereka, wali nikah, dan pihak yang berkepentingan mengenai halhal yang berkenaan dengan :

a. Adanya perkawinan dalam penyelesaian rangkaian perceraian;

b. Hilangnya akta nikah;

c. Adanya keraguan tentang sah atau tidaknya salah satu syarat perkawinan;

d. Adanya perkawinan sebelum adanya Undang-Undang Nomor 1 Tahun 1974 tentang Perkawinan;

e. Perkawinan yang diajukan oleh mereka yang tidak terdapat halangan perkawinan menurut Undang-Undang Nomor 1 Tahun 1974.

Pencatatan perkawinan sifatnya adalah administratif tetapi mempunyai fungsi untuk menjamin hak-hak suami atau isteri yang timbul sebagai akibat hukum dari perkawinan. Syarat pencatatan perkawinan yang telah ditetapkan oleh pemerintah merupakan cara untuk menjamin kepastian hukum warga negaranya. Salah satunya adalah perlindungan hak atas harta bersama bagi suami ataupun isteri terkait harta bersama.

Perkawinan sirri atau perkawinan di bawah tangan jika terjadi perceraian masih bisa mendapatkan hak atas harta bersama setelah adanya penetapan pengadilan. Untuk yang beragama islam perkawinan sirri bisa mengajukan penetapan perkawinan di Pengadilan Agama yaitu itsbat nikah. Untuk yang beragama selain islam dapat melakukan perkawinan ulang di hadapan petugas pencatat nikah. Perkawinan ulang ini agak sulit dilakukan jika tujuannya adalah untuk melakukan perceraian pasangan sehingga yang lebih lazim digunakan adalah permohonan itsbat nikah.

Pembagian harta bersama menurut Pasal 37 Undang-Undang Nomor 1 Tahun 1974 tentang Perkawinan. Jika terjadi perceraian maka pembagian harta diatur menurut hukumnya masing-masing. Pasal 97 Kompilasi Hukum Islam, masing-masing janda atau duda cerai hidup mendapatkan seperdua (1/2) dari harta bersama selama tidak

7Detiknews, Fatwa MUI: Nikah Sirri Sah, https://news.detik.com/berita/605475/fatwa-muinikah-siri-sah, Diakses pada 29 Juli 2019 Pukul 20.03. 
ditentukan lain dalam perjanjian perkawinan. Pembagian tersebut sesuai dengan yurisprudensi Mahkamah Agung RI No. 424.K/ sip.1959 tertanggal 9 Desember 1959, jika terjadi perceraian, maka masing-masing suami isteri bercerai mendapatkan setengah dari harta bersama. Akan tetapi peraturan tersebut tidak secara rigid diberlakukan. Pembagian harta bersama bisa dilakukan dengan musyawarah antara kedua belah pihak sehingga mendapatkan kesepakatan tanpa adanya unsur keterpaksaan. Hakim dalam memutuskan pembagian harta bersama terkadang juga melihat kondisi perkawinan pasangan. Contohnya putusan MA No. 266K/AG/2010, memutuskan memberikan tiga perempat (3/4) bagian kepada isteri dan sisanya seperempat $(1 / 4)$ bagian kepada suami karena berdasarkan fakta dan bukti di persidangan suami tidak memberikan nafkah dan seluruh harta bersama diperoleh dari hasil kerja isterinya sendiri.

\section{PENUTUP}

Selama ini masih banyak masyarakat yang melaksanakan perkawinan sirri atau di bawah tangan dimana maksudnya adalah melaksanakan perkawinan sesuai dengan agama dan kepercayaan, memenuhi rukun dan syarat perkawinan akan tetapi tidak dicatatkan kepada lembaga pencatat perkawinan. Menurut fatwa MUI perkawinan tersebut sah selama memenuhi syarat dan sahnya perkawinan. Akan tetapi hal tersebut dapat menimbulkan masalah dalam menuntuk hak masing-masing suami isteri salah satunya terkait harta bersama. Untuk mengatasi masalah tersebut, Kompilasi Hukum Islam mengatur penetapan perkawinan oleh pengadilan atau itsbat nikah. Setelah adanya penetapan tersebut berakibat berlakunya hukum pembagian bersama sebagaimana di atur dalam Pasal 37 UUP, Pasal 97 KHI, masing-masing mendapatkan seperdua, musyawarah para pihak, atau sesuai dengan putusan pengadilan dimana pertimbangan hakim melihat kondisi kehidupan perkawinan pasangan tersebut.

Adanya polemik terkait pembagian harta bersama tersebut perlu adanya formulasi peraturan pembagian harta bersama dalam peraturan perundang-undangan agar mengakomodir hak kedua belah pihak, masing-masing suami isteri.

\section{DAFTAR PUSTAKA}

Undang-Undang Nomor 1 Tahun 1974 tentang Perkawinan

Instruksi Presiden Nomor 1 Tahun 1991 tentang Kompilasi Hukum Islam

Undang-Undang Nomor 23 Tahun 2006 tentang Administrasi Kependudukan

Peraturan Pemerintah Nomor 9 Tahun 1975 tentang Pelaksanaan Undang-Undang

Nomor 1 Tahun 1974 Tentang Perkawinan

Hilman Hadikusuma, Hukum Perkawinan Indonesia Menurut Perundangan, Hukum

Adat, Hukum Agama, Bandung: Mandar Maju, 2003

Pusat Bahasa Departemen Pendidikan Nasional, Kamus Umum Bahasa Indonesia, Jakarta: Balai Pustaka, 2007

Sudikno Mertokusumo, Mengenal Hukum Suatu Pengantar, Yogyakarta: Penerbit Liberty, 2003 
Itsnaatul Latifah, Pencatatan Perkawinan: Melacak Akar Budaya Hukum dan Respon Masyarakat Indonesia Terhadap Pencatatan Perkawinan, Jurnal Al Mazahib, Vol. 3, No. 1, Juni 2015

Kementerian Pemberdayaan Perempuan dan Perlindungan Anak, Perkawinan Sirri dan Dampaknya di Provinsi Jawa Barat, https://www.kemenpppa.go.id/lib/uploads/list/34529-laporan-riset-perkawinansirri-dan-dampaknya.pdf, diakses pada 25 Juli 2019 Pukul 08.20

Detiknews, Fatwa MUI: Nikah Sirri Sah, https://news.detik.com/berita/605475/fatwamui-nikah-siri-sah, Diakses pada 29 Juli 2019 Pukul 20.03 